\title{
Plant spacing and phosphate fertilization on costus ${ }^{(1)}$
}

\author{
PETTERSON BAPTISTA DA LUZ ${ }^{(2)}$, SEVERINO DE PAIVA SOBRINHO(2), ARMANDO REIS TAVARES(3)
}

\begin{abstract}
The Cheilocostus speciosus is a species with ornamental potential, but the lack of scientific and technical information for fertilization and management of cut flowers production, turns essential to research in this area on floriculture. The aim of this work was to evaluate the production of $C$. speciosus fertilized with different levels of phosphate and plant spacing. Four treatments were used in a factorial scheme, with two plant spacing $(1.20 \times 0.80 \mathrm{~m}$ and $1.20 \times 1.60 \mathrm{~m})$ and two levels of phosphate fertilization (35 and $70 \mathrm{~g}$ per plant). The variables analyzed were number of vegetative stems, clump height, number of inflorescences, inflorescence diameter, inflorescence height and stem with inflorescence height. The interaction plant spacing and $\mathrm{P}$ doses for height of stem with inflorescence showed that the $1.20 \times 0.8 \mathrm{~m}$ spacing presented the best results independently of the $\mathrm{P}$ dose applied and for clump height treatment the spacing $1.20 \times 0.80 \mathrm{~m}$ and $35 \mathrm{~g}$ P showed the best results. Phosphorus fertilization had no effect on C. speciosus flower production for all other variables analyzed, and the spacing $1.2 \times 0.8 \mathrm{~m}$ is recommended for C. speciosus flower production. Keywords: tropical flower, fertilization, phosphate, Costaceae.
\end{abstract}

\section{RESUMO}

\section{Espaçamento e adubação fosfatada em costus}

O costus (Cheilocostus speciosus) é espécie nativa ornamental, com excelente potencial para a produção de flores de corte, entretanto a falta de informações científicas e técnicas para a adubação e manejo da cultura é um dos principais entraves para a expansão do seu cultivo. O trabalho teve como objetivo avaliar a produção de costus em Cáceres (MT), a partir de diferentes níveis de adubação fosfatada e espaçamentos de plantio. Foram empregados 4 tratamentos em esquema fatorial, constituídos por dois espaçamentos $(1,20 \times 0,80 \mathrm{~m} \mathrm{e} 1,20 \times 1,60 \mathrm{~m})$ e duas doses de adubação fosfatada ( 35 ou $70 \mathrm{~g}$ superfosfato simples por planta). As variáveis analisadas foram: número de hastes vegetativas, altura da touceira, número de inflorescências, diâmetro da inflorescência, altura da inflorescência e altura média da haste com inflorescência. A interação espaçamento entre plantas e doses de P para comprimento da haste com inflorescência mostraram que o espaçamento de $1,20 \times 0,8 \mathrm{~m}$ apresentou os melhores resultados independentemente da dose de P aplicada e para o tratamento da altura da touceira os espaçamentos 1,20 x 0,80 m e $35 \mathrm{~g}$ de P apresentaram os melhores resultados. A adubação fosfatada não teve efeito sobre a produção de flores de C. speciosus e demais variáveis analisadas, sendo recomendado o espaçamento 1,2 × 0,8 m para a produção de flores de C. speciosus.

Palavras-chave: flor tropical, adubação, fosfatada, Costaceae.

\section{INTRODUCTION}

The use of tropical plants for floriculture has emerged in recent years as a viable alternative, considering their eccentricity, exuberance and longevity of flowers during the post-harvest period of these species. Such characteristics make tropical flowers attractive to so many consumers (LAMAS, 2004). The cultivation of flowers and tropical plants for use in ornamentation has been increasing and the main cultivated species are anthurium, heliconia, alpinia, costus, gingers and golden beehive ginger. Costaceae species have potential to be used in all floriculture sectors such as cut flower, cut stem, pot plant and landscape design (CASTRO et al., 2011).

The Zingiberales order currently includes eight genera in Costaceae family, comprising about 120 species, including Cheilocostus speciosus, with natural occur- rences throughout to Southeast Asia and surrounding regions (CASTRO et al., 2012). Cheilocostus genus includes "large" plants $(>1.5 \mathrm{~m})$, leaves are seasonally deciduous and attached to sheath by short petiole, inflorescence as an elongate spike, terminal either emerging directly from the rhizome on a leafless stem or terminating a vegetative shoot and large labellum colored white, yellow to orange and sometimes red (SPECHT and STEVENSON, 2006).

The choice of plant spacing for Costus is directly associated to plant size, and may vary from 1.5 to $2.0 \mathrm{~m}$ between rows and 0.4 to $2.0 \mathrm{~m}$ between plants, and the use of organic fertilizers is recommended in order to avoid compounds rich in urea, and if necessary in denser plant planting the fertilization with high amounts of potassium (CASTRO et al., 2012). Plant density acts as a key factor in regulating plant competition within the population and optimal plant densities are very important for effi-

DOI: http://dx.doi.org/10.14295/oh.v24i3.1211

(1) Received in 16/05/2018 and accepted in 10/08/2018

${ }^{(2)}$ Universidade do Estado de Mato Grosso (UNEMAT), Cáceres-MT, Brazil. *Corresponding author: petterbaptista@yahoo.com.br

${ }^{(3)}$ Instituto de Botânica (IBt), São Paulo-SP, Brazil.

Licensed by CC BY 4.0 
cient agronomic practice aiming to maximize yield in crops (JIANG et al., 2013). Some advantages of reduced row spacing include the more efficient use of environmental resources, better weed control and higher grain yield (STRIEDER et al., 2008). Corn yield correlates significantly with planting density, planting and harvest date, and NPK fertilization (ASSEFA et al., 2014). The criteria used for management and evaluation of ornamental crops production, when compared to other crops, are less rigid and, frequently based on concepts and experiments conducted by producers. The selection of spacing is directly associated with plant size and the final product; organic fertilizers are also recommended in order to avoid compounds rich in urea, and if necessary, for denser plant spacing the use of compounds with higher quantities of potassium (K) are required (CASTRO et al., 2012).

Nutrients play important roles in plants physiology and some nutrients are directly related to flower buds formation; however, nutrient excess or deficiency may adversely affect crop production, mostly influencing flowers and/or inflorescences quality and post-harvest vase life (BECKMANN-CAVALCANTE et al., 2009). There are no technical official recommendation for Cheilocostus fertilization and, for costus fertilization it has be done in an empirical way, based on the recommendation for other families and with no differences for cut flowers, garden plants or potted plants production (MERIDA, 2017). Nutrients considered essential for plant development as phosphorus (P) have a prominent role, influencing complex structural processes such as biomass production and participating of formation and absorption of vital compounds for plants. Phosphorus absorption occurs predominantly on ionic form, and is accumulated in the cortical cells of the root, followed by the transfer of the element to the xylem through the simplasto, reaching the leaves or the growth sites (MALAVOLTA, 2006; TAIZ and ZEIGER, 2017). Phosphorus has a significant interaction with other macronutrients, which is associated with improvement in growth and yield of crop plants with the P fertilization (FAGERIA, 2016).

The lack of scientific and technical information for fertilization and crop management for cut flowers production, especially tropical species, limit the expansion of production area of this potential important sector of Brazilian floriculture. The aim of this study was to evaluate the effect of different levels of phosphate fertilization and plant spacing on $C$. speciosus production.

\section{MATERIAL AND METHODS}

The experiment was conducted from December 2013 to June 2014 at 6 $6^{\circ} 35.52^{\prime \prime S}$ and 57³9'8.92”W. The experimental area is hot and humid, with average annual temperature of $26.4{ }^{\circ} \mathrm{C}$ and maximum of $41.2{ }^{\circ} \mathrm{C}$, a well-defined dry and rainy season, with higher precipitation on March (NEVES et al., 2011). The soil of experimental field is classified as Plintossolo Pétrico Concrecionário Distrófico (EMBRAPA, 2007), composed of sand (617 $\left.\mathrm{g} \mathrm{kg}^{-1}\right)$, silt (145 g $\left.\mathrm{kg}^{-1}\right)$ and clay $\left(337 \mathrm{~g} \mathrm{~kg}^{-1}\right)$. The soil chemical analysis showed $28.0 \mathrm{~g} \mathrm{dm}^{-3}$ of organic matter and $\mathrm{pH}$ of 6.1 ; with $90.5 \mathrm{mg}$ $\mathrm{dm}^{-3}$ of P; $0.33 \mathrm{cmol} \mathrm{dm}^{-3} \mathrm{~K} ; 5.19 \mathrm{cmol}_{c} \mathrm{dm}^{-3} \mathrm{Ca} ; 1.94 \mathrm{cmol}_{c}$ $\mathrm{dm}^{-3} \mathrm{Mg} ; \mathrm{CTC}=8.3 \mathrm{cmol}_{\mathrm{c}} \mathrm{dm}^{-3}$ and $\mathrm{V} \%=89.40 \%$. The soil of the area was tilled and the irrigation system was a drip irrigation system, performed four times a week before dawn. During experimentation data of mean temperature, solar radiation and precipitation were collected daily in the Meteorological Station of UNEMAT (Figure 1). 

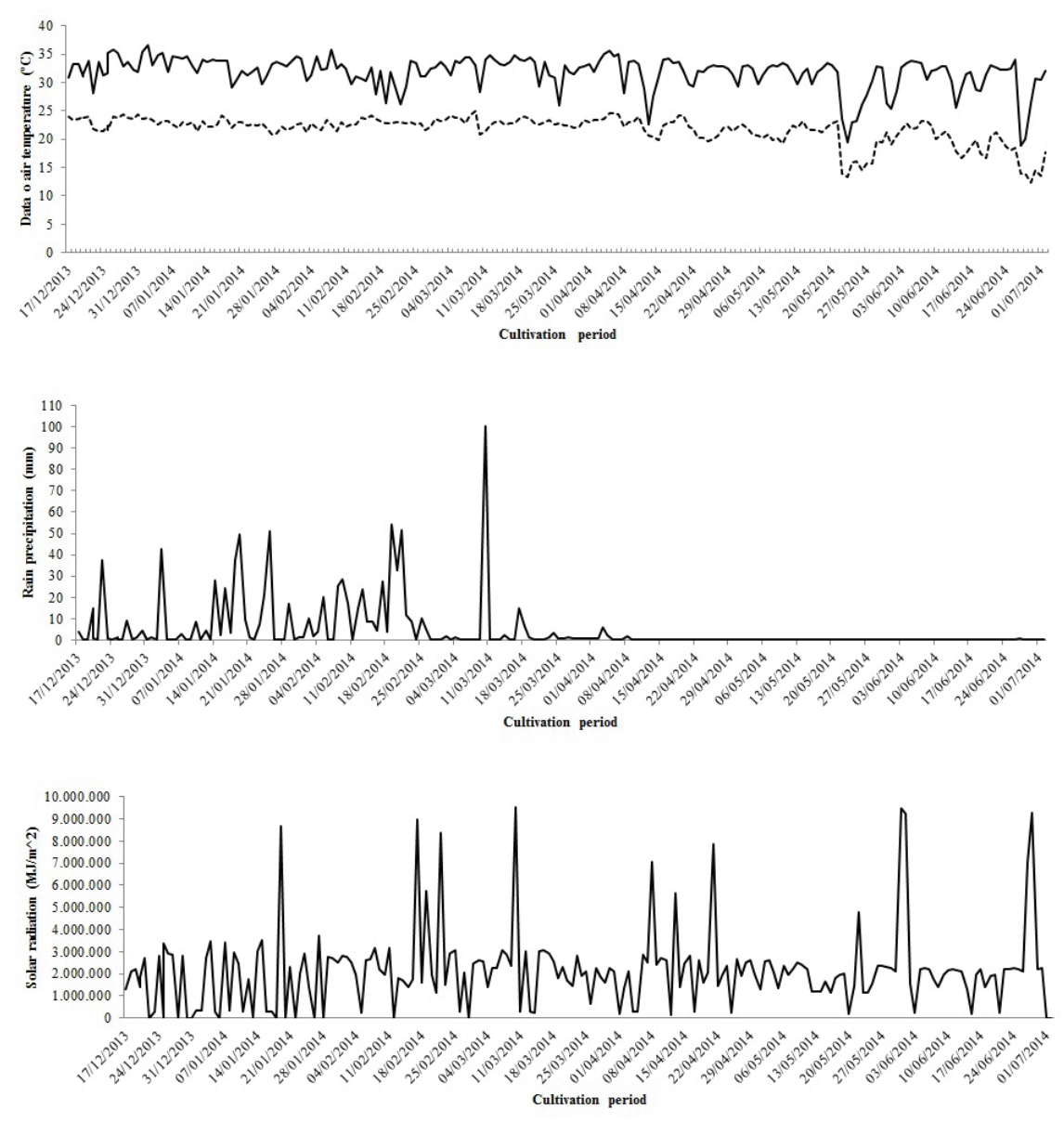

Figure 1. Air temperature (A), rain precipitation (B) and solar radiation (C) during the experimentation with Cheilocostus speciosus.

C. speciosus seedlings used on experiment were obtained from cuttings removed of the apical part of the plants (10 cm from the base) and, placed in sand to stimulate roots and shoots emission for 30 days. The plants used on experiment were rooted seedlings with $15-20 \mathrm{~cm}$ length shoots.

The plants were cultivated on two spacing: $1.0-1.20 \mathrm{~m}$ between plants and $0.80 \mathrm{~m}$ between rows and, 2.0-1.20 m between plants and $1.60 \mathrm{~m}$ between rows and two levels of phosphate fertilization (LEE et al., 2008, adapted): 35 g simple superphosphate (18\% P, $4.54 \mathrm{~g}$ urea and $7.14 \mathrm{~g}$ $\mathrm{KCl}$ ), and $70 \mathrm{~g}$ of single superphosphate, monthly applied during all experimentation. The fertilization was placed around of each plant (10 cm from the center).

The agronomic characters were adapted of Souza et al. (2016) and were evaluated the number of vegetative stems (NVS), number of inflorescences (NI), inflorescence diameter (ID), inflorescence height (IH), height of stem with inflorescence (HSI) and clump height $(\mathrm{CH})$.

The experimental design was $2 \times 2$ factorial in a randomized block design with 5 replicates and 6 plants per plot. Data were submitted to analysis of variance and the means compared by the Tukey test at 5\% probability and processed by SISVAR program (FERREIRA, 2011).

\section{RESULTS AND DISCUSSION}

The development of $C$. speciosus plants showed a precocity in relation to flowering period when compared to other tropical species such as Heliconia cv. Golden Torch (BECKMANN-CAVALCANTE et al., 2015), which usually start producing inflorescences at 4 months, golden beehive ginger (Zingiber spectabile) starting at 16 months (UNEMOTO et al., 2012), anthurium (Anthurium andraeanum) starting at 4 months (FAVA and CAMILI, 2014) and bird of paradise (Strelitzia reginae) starting at 9 months the emission of first inflorescences (FAVA et al., 2015).

The establishment of plant flowering was adopted as a criterion to evaluate the six agronomic characters (Table 1). Significant differences were observed on phosphorus doses and plant spacing interaction for the variables height of stem with inflorescence (HSI) and clump height $(\mathrm{CH})$. 
Table 1. Influence of plant spacing and phosphorus doses on plants of Cheilocostus speciosus for the variables number of vegetative stems (NVS), number of inflorescences (NI), inflorescence diameter (ID), inflorescence height (IH), height of stem with inflorescence (HSI) and clump height $(\mathrm{CH})$.

\begin{tabular}{|c|c|c|c|c|c|c|c|}
\hline & NVS & NI & ID & IH & HSI & CH \\
\hline Variation & $(\mathbf{u n})$ & $(\mathbf{u n})$ & $\mathbf{( m m )}$ & $\mathbf{( c m )}$ & $\mathbf{( c m )}$ \\
\hline Plant spacing (PS) & $1.6000^{\text {ns }}$ & $4.9000^{\text {ns }}$ & $5.9059^{\text {ns }}$ & $0.3027^{\text {ns }}$ & $4577.4602^{* *}$ & $2325.6250^{* *}$ \\
\hline Phosphorus doses (P) & $0.4000^{\text {ns }}$ & $40.0000^{\text {ns }}$ & $5.1051^{\text {ns }}$ & $0.0518^{\text {ns }}$ & $283.6627^{\text {ns }}$ & $15.6250^{\text {ns }}$ \\
\hline PS x P interation & $8.1000^{\text {ns }}$ & $3.6000^{\text {ns }}$ & $5.5726^{\text {ns }}$ & $0.1795^{\text {ns }}$ & $1054.5236^{* *}$ & $416.0250^{*}$ \\
\hline CV (\%) & 18.39 & 35.41 & 11.56 & 9.11 & 9.43 & 9.02 \\
\hline
\end{tabular}

Significant at 5 and $1 \%$ of probability. $*$ and $* *$, respectively; ns-non-significant ( $p \geq 0.05$ and 0.01$)$; CV - coefficient of variation

The data observed on the agronomic characteristics (Table 2) allow inferring that plants spacing had a great contribution to variables HSI and $\mathrm{CH}$ with significant values on the lower spacing $(1.20 \times 0.80 \mathrm{~m})$. The variables ID, NI, IH and NVS were not influenced by plant spacing. These results may be related to a natural tendency to increase plant height, as the plant search for light to assist the photosynthetic process (ARGENTA et al., 2001).
Plant spacing objective to provide sufficient space for each plant to obtain maximum growth and production. As plant growth, there is an increase on demand for nutrients, light, water and space for roots and aerial system development, creating a great competition between plants and wider plant spacing tend to produce greater dry matter, while smaller ones produce greater biomass per area and higher plant height (SILVEIRA, 2014).

Table 2. Effect of plant spacing and phosphorus doses on Cheilocostus speciosus plants variables stem height with inflorescence (HSI) and clump height $(\mathrm{CH})$.

\begin{tabular}{|c|c|c|c|c|}
\hline \multirow{2}{*}{ Variables (cm) } & Phosphorus (g) & \multicolumn{2}{|c|}{ Plant spacing (m) } & CV (\%) \\
\hline \multirow{2}{*}{ HSI } & 35 & $1.20 \times 0.80$ & $1.20 \times 1.60$ & 9.43 \\
\hline \multirow{2}{*}{$\mathrm{CH}$} & 70 & $137.5 \mathrm{Aa}$ & $105.84 \mathrm{Bb}$ & 9.02 \\
\hline
\end{tabular}

Means followed by the same lowercase letters in the row and upper case in the column do not differ by Tukey test at $5 \%$ probability.

Phosphorus fertilization had no effect for all variables (Table 1). Phosphorus fertilization alone seems to be not effective to promote plant growth and yield in ginger (SINGH et al., 2003); additionally high doses of phosphorus as $60 \mathrm{P}_{2} \mathrm{O}_{5} \mathrm{~kg} \mathrm{ha}^{-1}$ decreased rhizome yield (YADAV et al., 1983). Indeed, excess phosphorus fertilization in ginger may adversely affect crop growth by direct phytoxicity of the element or by immobilization of elements such as copper, zinc or iron forming insoluble phosphates (phosphorus-induced deficiencies) (ASHER and LEE, 1975).

The interaction plant spacing $\mathrm{x} P$ doses for HSI showed that the $1.20 \times 0.8 \mathrm{~m}$ spacing presented the best results independently of the $\mathrm{P}$ dose applied and for $\mathrm{CH}$ treatment the spacing $1.20 \times 0.80 \mathrm{~m}$ and $35 \mathrm{~g} P$ showed the best results (Table 2). Unemoto et al. (2012), studying the growth of golden beehive ginger did not observe differences on inflorescence stem length and inflorescence length on different plant spacing, however the number of inflorescence increase in higher plant spacing. A larger number of inflorescences of Alpinia cv. Porcelana were produced in the smallest spacing $(2.1 \times 2.2 \mathrm{~m})$ treatment (NASCIMENTO et al., 2015); thus, $50 \%$ of shade increase inflorescence quality if compared to inflorescence of plants cultivated at full sun. Alpinia plants showed higher production with plant spacing ranging from 1.0-2.0 m between plants and 2.0-3.0 m between rows (TEIXEIRA and LOGES, 2008).

Significant additions to crop production in smaller plant spacing demand a great use of fertilization, and higher competition for nutrients and water, a reduction of solar radiation; however, allows a better use and occupation of the area (IBIAPABA et al., 2000). The significant increase in ginger (Zingiber officinale) yield per hectare under small 
spacing might be on the function that higher plant density per unit area allow an efficient availability and utilization of nutrients by the growing plants (MAHENDER et al., 2015). The decrease of plant spacing increase ginger (Zingiber officinale) yield; however, the small plant spacing significantly increase in percent of rhizome rot and wilt disease incidence in plants (SHARMA et al., 2012).

\section{CONCLUSIONS}

The interaction plant spacing and $\mathrm{P}$ doses for height of stem with inflorescence showed that the $1.20 \mathrm{x} 0.8 \mathrm{~m}$ spacing presented the best results independently of the $\mathrm{P}$ dose applied and for clump height treatment the spacing $1.20 \times 0.80 \mathrm{~m}$ and $35 \mathrm{~g}$ P showed the best results. Phosphorus fertilization had no effect on C. speciosus flower production for all other variables analyzed, and the spacing $1.2 \times 0.8 \mathrm{~m}$ is recommended for $C$. speciosus flower production.

\section{AUTHORS CONTRIBUTIONS}

P.B.L: (10000-0003-4067-0087: conception and design of the research, obtaining data, analyze and interpretation of data, statisticalanalysis, writeandcriticallyanalyses ofmanuscript. S.P.S.: (D)000-0002-7989-8145: obtaining data, analyze and interpretation of data, statistical analysis, write and critically analyses of manuscript. A.R.T.: (10000-0001-6006-4741. analyze and interpretation of data, statistical analysis, write and critically analyses of manuscript.

\section{REFERENCES}

ARGENTA, G.S.; SILVA, P.R.F.; BORTOLINI, C.G.; FORSTHOFER, E.L.; MANJABOSCO, E.A.; BARROS NETO, V. Resposta de híbridos simples à redução do espaçamento entre linhas. Pesquisa Agropecuária Brasileira, v.36, n.1, p.1-78, 2001. DOI: http://dx.doi. org/10.1590/S0100-204X2001000100009

ASHER, C.J.; LEE, M.T. Diagnosis and correction of nutritional disorders in ginger. Brisbane: Watson, Ferguson \& Co., 1975.

ASSEFA, Y.; ROOZEBOOM, K.; THOMPSON, C.; SCHLEGEL, A.; JANE, L.S.; LINGENFELSER, E. Corn and grain sorghum yield trend since the beginning of hybrid technology. In: Corn and Grain Sorghum Comparison. ASSEFA, Y.; ROOZEBOOM, K.; THOMPSON, C.; SCHLEGEL, A.; JANE, L.S.; LINGENFELSER, E. Oxford: Academic Press, 2014. p.31-56.

BECKMANN-CAVALCANTE, M.Z.; AMARAL, G.C.; AVELINO, R.C.; SILVA, A.A.; SILVA, A.S.; OLIVEIRA, J.B.S. Produção de inflorescências de helicônia cv. Golden Torch sob adubação nitrogenada e potássica. Comunicata Scientiae, v.6, n.1, p.65-73, 2015.
BECKMANN-CAVALCANTE, M.Z; PIVETTA, K.F.L.; CAVALCANTE, Í.H.L.; CAVALCANTE, L.F.; BELLINGIERI, P.A. Soluções nutritivas no desenvolvimento do crisântemo cultivado em vaso. Irriga, v.14, p.205- 219, 2009.

CASTRO, C.E.F.; GONÇALVES, C.; MOREIRA, S.R.; FARIA, O.A. Costus e outras espécies da família Costaceae. In: PAIVA, P.D.O.; ALMEIDA, E.F.A. Produção de flores de corte, v.1. Lavras: Editora UFLA, 2012. 678p.

CASTRO, C.E.F.; MOREIRA, S.R.; CASTRO, A.C.R.; SOUZA, F.V.D.; LOGES, V.; GONÇALVES, C.; COSTA, M.A.P.C.; MOURA, L.F. Avaliação de espécies Costaceae para uso ornamental. Revista Brasileira de Horticultura Ornamental, v.17, n.1, p.63-74, 2011. DOI: https://doi. org/10.14295/rbho.v17i1.719

EMBRAPA. Sistema brasileiro de classificação de solos. Brasília: Embrapa, 2007. 412p.

FAGERIA, N.K. The use of nutrients in crop plants. Boca Raton, London, New York: CRC press, 2016. 430p.

FAVA, C.L.F.; CAMILI, E.C. Produção de cultivares de Anthurium andraeanum nas condições de Acorizal-MT. Revista Brasileira de Horticultura Ornamental, v.20, n.2, p.179-184, 2014.

FAVA, C.L.F.; GIACHINI, R.M.; SILVA, J.L.; ANTUNES JÚNIOR, M.Z.; SILVA, T.J.A. Sombreamento na produção inicial de hastes florais de Strelitzia reginae em Acorizal, MT. Ornamental Horticulture, v.21, n.1, p.39-46, 2015. DOI: $10.14295 /$ rbho.v21i1.774

FERREIRA, D.F. Sisvar: a computer statistical analysis system. Ciência e Agrotecnologia, v.35, n.6, p.10391042, 2011. DOI: http://dx.doi.org/10.1590/S141370542011000600001

IBIAPABA, M.V.B.; LUZ, J.M.Q.; INNECCO, R. Avaliação do espaçamento de plantio de Heliconia psittacorum L., cultivares 'Sassy' e 'Andromeda'. Ciência e Agrotecnologia, v.24, p.181-186, 2000.

JIANG, W.; WANG, K.; WU, Q.; DONG, S.; LIU, P.; ZHANG, J. Effects of narrow plant spacing on root distribution and physiological nitrogen use efficiency in summer maize. The Crop Journal, v.1, n.1, p.77-83, 2013. DOI: https://doi.org/10.1016/j.cj.2013.07.011

LAMAS, A.M. Flores: produção, pós-colheita e mercado. Fortaleza: Instituto Frutal, 2004. 109p.

LEE, J.S.; LEE, A.K.; SUH, J.K. 2008. Optimum nutrient level on growth, flowering, and rhizome production in curcuma. Journal of Plant Nutrition, v.31, n.12, p.2183-2195, 2008. DOI: https://doi. org/10.1080/01904160802463270 
MAHENDER, B.; REDDY, P.S.S.; SIVARAM, G.T.; BALAKRISHNA, M.; PRATHAP, B. Effect of seed rhizome size and plant spacing on growth, yield and quality of ginger (Zingiber officinale Rosc.) under coconut cropping system. Plant Archives, v.15, n.2, p.769-774, 2015.

MALAVOLTA, E. Manual de nutrição mineral de plantas. São Paulo: Ceres, 2006. 638p.

MERIDA, D.; PIVETTA, K.F.L.; MAZZINI-GUEDES, R.B.; CASTRO, C.E.F.; PURQUERIO, L.F.V. Effects of nitrogen fertilization on development, flowering, and mineral nutrition of potted Costus productus Gleason ex Maas. Journal of Plant Nutrition, v.40, n.7, p.1045-1052, 2017. DOI: https:// doi.org/10.1080/01904167.2016.1263327

NASCIMENTO, A.M.P.; PAIVA, P.D.O.; NERY, F.N.; SOUZA, R.R.; MANFREDINI, G.M.; ALMEIDA, E.F.A.A. Influência do espaçamento de plantio e luminosidade no desenvolvimento de bastão-do-imperador. Revista Brasileira de Ciências Agrárias, v.10, n.2, p.230236, 2015. DOI: 10.5039/agraria.v10i2a5103

NEVES, S.M.A.; NUNES, M.C.M.; NEVES, R.J. Caracterização das condições climáticas de Cáceres/MT Brasil, no período de 1971 a 2009: Subsídio às atividades agropecuárias e turística municipais. Boletim Goiano de Geografia, v.31, n.2, p.55-68, 2011. DOI: https://doi. org/10.5216/bgg.v31i2.16845

SHARMA, B.R.; DUTTA, S.; RAY, S.; ROY, S. Influence of plant spacing, seed rhizome size and cultivars on the incidence of rhizome rot and wilt disease complex of ginger. Journal of Horticulture and Forestry, v.4, n.12, p.105-107, 2012. DOI: https://doi.org/10.5897/JHF09.045

SILVEIRA, E.R. Efeito do espaçamento de plantio na produção de madeira e serapilheira de Eucalyptus dunni na região sudoeste do Paraná. Revista Técnico Científica, v.1, n.2, 2014.
SINGH, A.; SINGH, B.; SINGH, A.; SINGH, P. Response of ginger (Zingiber officinale) to methods of planting and levels of phosphorus in a rehabilitated forest developed on sodie land. Journal of Spices and Aromatic Crops, v.12, n.1, p.63-66, 2003. DOI: http://dx.doi.org/10.1016/j. jep. 2012.10 .043

SPECHT, C.D.; STEVENSON, D.W. A new phylogenybased generic classification of Costaceae (Zingiberales). Taxon, v.55, n.1, p.153-163, 2006. DOI: https://doi. org/10.2307/25065537

STRIEDER, M.L.; SILVA, P.R.F.D.; RAMBO, L.; SANGOI, L.; SILVA, A.A.D.; ENDRIGO, P.C.; JANDREY, D.B. Crop management systems and maize grain yield under narrow row spacing. Scientia Agricola, v.65, n.4, p.346-353, 2008. DOI: http://dx.doi.org/10.1590/S010390162008000400004

TAIZ, L.; ZEIGER, E. Fisiologia vegetal. 6ed. Porto Alegre: Artmed, 2017. 888p.

TEIXEIRA, M.C.F.; LOGES, V. Alpinia - cultivo e comercialização. Revista Brasileira de Horticultura Ornamental, v.14, p.9-14, 2008.

UNEMOTO, L.K.; FARIA, R.T.; ASSIS, A.M.; LONE, A.B.; YAMAMOTO, L.Y. Cultivo de bastão-do-imperador sob diferentes espaçamentos em clima subtropical. Ciência Rural, v.42, n.12, p.2153-2158, 2012. DOI: http://dx.doi. org/10.1590/S0103-84782012005000094

YADAV, R.L.; ANWAR, M.; SINGH, R.; SINGH, D.V. Response of Costus speciosus Koen. to nitrogen, phosphorus and potassium fertilizer. The Journal of Agricultural Science, v.101, n.3, p.755-756, 1983. DOI: https://doi. org/10.1017/S0021859600038818 